\title{
COMMERCIALIZATION OF RESULTS OF THE SPACE ACTIVITY: GLOBAL PRACTICES, CHALLENGES AND PROMISING AREAS"
}

\author{
Sergei V. MAKAROV a, , Oleg E. KHRUSTALEV ${ }^{\mathrm{b}}$ \\ a Central Economics and Mathematics Institute, Russian Academy of Sciences (CEMI RAS), \\ Moscow, Russian Federation \\ sergei.makarov@gmail.com \\ ORCID: not available \\ ${ }^{\mathrm{b}}$ Central Economics and Mathematics Institute, Russian Academy of Sciences (CEMI RAS), \\ Moscow, Russian Federation \\ stalev777@yandex.ru \\ ORCID: not available \\ - Corresponding author
}

\section{Article history:}

Received 8 June 2018

Received in revised form

15 June 2018

Accepted 26 June 2018

Available online

28 June 2019

JEL: O14, O25, O32, O33

Keywords: space activity, commercialization, efficiency evaluation, financial costs, innovative project

\begin{abstract}
Subject The article discusses issues of reducing financial costs incurred by scienceintensive and high-tech enterprises to engineer aerospace equipment and cut costs of various space services rendered through satellite technology. To accelerate the advancement of the aerospace production, Russia should reshape the industry by involving private business on an arm length's basis.

Objectives The study examines, adapts foreign practices, develop new comprehensive toolbox for effective integration of State corporations and private business.

Methods The proposed method is based on general scientific principles, comprehensive use of the systems analysis methodology, enhanced expert assessment technique revealing the efficiency and competitiveness of all science-intensive and high-tech enterprises.

Results To make the commercialization of various types of space activity more effective, we typified and classified space services from consumers' perspectives, show the outcome of a comparative analysis of national and international space markets through history and substantiate new form of cooperation between space and on-shore manufacturing sectors. The proposed techniques and tools reveal new trends in the commercialization of space services, effective generation of possible market formation alternatives, promising aspects of demand. They help evaluate their impact on space technologies and reciprocal effects.

Conclusions and Relevance The system studies of the space activity pursue the technological advancement of aerospace systems and more effective governance of Roscosmos entities and global expansion of the position and opportunities of the Russian aerospace industry by involving private businesses and commercializing space services.
\end{abstract}

(C) Publishing house FINANCE and CREDIT, 2018

The editor-in-charge of this article was Irina M. Vechkanova

The authorized translation by Irina M. Vechkanova

Please cite this article as: Makarov S.V., Khrustalev O.E. Commercialization of Results of the Space Activity: Global Practices, Challenges and Promising Areas. Digest Finance, 2019, vol. 24, no. 2, pp. 135 - 148.

https://doi.org/10.24891/df.24.2.135

\section{Introduction}

The market in space and space in the market is what best describes the economic prospects

\footnotetext{
"For the source article, please refer to: Макаров С.В., Хрусталёв О.Е. Коммерциализация результатов космической деятельности: мировой опыт, проблемы и перспективные направления. Экономический анализ: теория и практика. 2018. T. 17. № 7. C. 1379-1396.

URL: https://doi.org/10.24891/ea.17.7.1379
}

of space activities. The commercialization of results of space activities contributes to economic growth, innovation, national security. It may become a driving force for recovering, strengthening and expanding the space industry, making it another driver of the Russian economy. However, the commercialization will require some 
conceptual rearrangements of the organizational design of the industry.

The government might revise the current format of the space industry, which used to be a totally inaccessible sector (since it mostly dealt with defensive missions), and convert it into a more flexible market organism, like public-private partnership. Private space business has been demonstrating an active growth in the USA for the recent years. However, it would be also early and unreasonable to adopt such practices in Russia as are since this requires preliminary research. Allowing private enterprises in the space industry should be necessarily regulated. There should be a condition that governmental programs should be performed by the most competent and effective contractors, notwithstanding their class.

The space development strategy should remain within the competence of the government. Setting out such a strategy, the government conducts a thorough analysis and maintains the balance of defensive and commercial interests. However, generally speaking, cost effectiveness of space activities is one of key metrics considered in space development planning. To prove this, A.R. Belousov, Aide to the President of the Russian Federation for Economic Affairs leveled his criticism at Roscosmos Corporation stating that it adopted an incorrect strategy and should better turn to the commercial path ${ }^{1}$.

The space commercialization has long attracted attention as an important issue to discuss. For example, E.M. Mekaeva [1] investigates the most critical matters, i.e. prospects and implications (positive and negative) of the commercialization. In their research, O.V. Firulev and Yu.V. Erygin [2] analyzed various concepts, such as potential,

\footnotetext{
${ }^{1}$ Kosmosu predlozhili vstroit'sya $v$ rynok [Space is offered to integrate into the market]. Kommersant, 2017, no. 232. URL: https://www.kommersant.ru/doc/3494887 (In Russ.)
}

commercialization of innovation, commercialization of aerospace innovation, etc. There are combined, systemic, resourcebased and strategic approaches to defining the term innovative potential. Scholars also explain the economic substance of commercializing the innovative potential of an integrated organization operating in the aerospace industry. I.V. Polukhin [3] specified the findings of the above studies by considering the role and specifics of the aerospace industry in Russia. S.K. Krikaleva and O.A. Saprykina [4] proposed scenarios for building the Lunar infrastructure from perspectives of public contractors and in terms of the commercialization of Lunar flights. In their study, V.V. Ivanitskaya and E.G. Korepanova examine promising aspects and methods for the commercial use of the space activity results and issues of involving private enterprises into these processes [5].

Therefore, the space industry should develop through the appropriate combination of efforts taken by specialized State corporations and private businesses that effectively managed specific technological and technical tasks.

\section{Key Historical Factors}

To ensure its innovative development, the space industry should smoothly substitute its defensive goals with civil ones, shifting from governmental control to arm length's methods, from national to international projects.

The space era commenced in 1957 when the first satellite was launched. Countries explored space independently. The period saw the construction of carriers delivering higher payload to the orbit, unmanned vehicles, people, and subsequent plans and voyages to other planets. Although pioneering projects pursued military goals, engineers attempted to solve initial civil tasks, which almost totally concerned communications. 
In the 1990s, the space industry faced new challenges of mapping and location. The new millennium is the time when the civil and, first of all, commercial use of space sprang. The U.S. Government chose to deploy the Global Positioning System (GPS) and fit nongovernmental devices with it. The manufacturing system and, ultimately, population got an opportunity to measure and use the coordinates and speed of objects.

The commercial sector is expanding its share in total space costs. In 2015, it reached 76 percent. The commercial use goes beyond national borders. The phase of isolation projects and measures was unavoidably superseded with the cooperation phase. During such integration processes, national laws and space regulations got into conflict, the number of artificial space objects in the orbit grew up considerably, thus necessitating the adoption of international space activity regulations [1].

We should make a special mention that private businesses have always been trailblazers of new products, technology, organizational forms of cooperation. Regulating business relations and space activities, in particular, the State basically fails to satisfy the current needs. It is quite ordinary for governmental control. Its conservative vision prevents the sectoral development from unacceptable formats. However, in some circumstances, it inhibits the spread of innovation which proved to be effective. For example, a growth in commercial launches and the number of commercial spacecraft is a serious problem for the USA since they lack special regulations for that.

They say that space does not have any palpable connection with the everyday life of ordinary people. Thus it is important to thoroughly segregate its impact and the extent to which it influences the public life. Ultimately, these are public needs and motivations that push the development of some area of activities people carry out, uniting in groups, communities and nations. As for space, there are three areas of public life which are mostly subject to its effects. These are national security, innovation and economy. Euroconsult, leading global consulting firm specializing in space markets ${ }^{2}$, provides key economic indicators of the space market. It also figures out economic facts which have close relationship with innovation as the second important area we mentioned.

According to the 2015 Report by the Satellite Industry Association (the USA) $)^{3}$, growth indicators of the space industry exceed the average of the U.S. national economy. There is the sustainable demand for launching small payload spacecraft to the orbit.

Although occupying small market niches, new segments of the space industry, such as space tourism and space mining (planets and asteroids), demonstrate an active pace. The segments cannot gain momentum so far due to the underdevelopment of respective technologies. In other words, the technologies are not yet effective to be massively applied. However, technological innovation is the area where the space industry takes the lead.

\section{Innovation}

It is difficult, if impossible, to predict modern innovation. Most innovations are virtually products of a combination merging several seemingly insignificant components into a working vehicle with its practical effect being surprisingly strong. This is true for both technological and organizational innovations.

Sizing of artificial space objects is the first matter that technological space innovation is called to solve. Dimensions and weight of

\footnotetext{
${ }^{2}$ Euroconsult. URL: http://www.euroconsult-ec.com/

${ }^{3}$ State of the Satellite Industry Report.

URL: http://www.sia.org/wp-content/uploads/2016/09/SSIR162016-09-23-Update.compressed.pdf
} 
artificial space objects launched to the outer space still remain the first and foremost economic constraint. It costs USD 20-30 thousand to launch a kilogram of space object to the orbit ${ }^{4}$. Correspondingly, the less the object, the cheaper its launch, the more objects can be started at a time. If the cost of a launch is decreased as expected ${ }^{5}$, it will be possible to considerably extend the list of objects that used to be economically ineffective. There is growing demand for small, lightweight and, consequently, cheap satellites to be launched ${ }^{6}$. Thus, their production induced the development and practical use of compact launchers. Compact rockets and satellites are especially popular in academic and scientific communities, allowing to produce various prototypes and subsequently test approaches, ideas and technologies. Academia and science are the cradle of innovation. Technology and materials resulting from space research migrate to other industries, serving for absolutely different purposes (as compared with the initial designation).

It is fair to say that technologies, which are designed as part of space programs, are put into terrestrial practice almost immediately after the launch of the first spacecraft. We should refer to the NASA website $^{7}$ that annually releases a list of technologies which were produced by NASA-supervised projects and became available to other developers and producers. As a matter of fact, this is a wellstructured catalog of technologies. Should the Russian space industry circulate such a catalog, the space and other industries would

\footnotetext{
${ }^{4}$ State of the Satellite Industry Report.

URL: http://www.sia.org/wp-content/uploads/2016/09/SSIR162016-09-23-Update.compressed.pdf

${ }^{5}$ Kramer S., Mosher D. Here's How Much Money It Actually Costs to Launch Stuff into Space.

URL: http://www.businessinsider.com/spacex-rocket-cargo-priceby-weight-2016-6/

${ }^{6}$ Batencourt M. Rise of the CubeSats.

URL: http://www.airspacemag.com/space/rise-cubesats180957827/

${ }^{7}$ NASA Spinoff. URL: https://spinoff.nasa.gov/
}

make a breakthrough in their cooperation. According to research by the Central Economics and Mathematics Institute of the Russian Academy of Sciences, mere ignorance and unawareness of some developers about research conducted by the other ones poses a serious problem $[6,7]$. They need to tackle the same tasks concurrently or further efforts can even become irrelevant at all because the solution is unknown, though it may be found by the other industry.

Ready-made services offered by the space industry is another form for cosmic and terrestrial industries. Communications is the first example to mention in this respect. Humankind believes that any progress is indispensable without an absolute coherence of its members, striving to make communications available for everyone. Making the Internet accessible for people worldwide is what major profit-making companies try to achieve through their futuristic projects ${ }^{8}$, which should be mentioned first of all, but some national campaigns pursue very ambitious goals.

\section{National Security}

This study does not focus on issues of defense. Thus we just make some remarks concerning aspects where interests of the State and private business overlap (in this case we mean issues of defense).

National security issues urged to create the space industry, remaining a considerable portion of the current space activities. According to the U.S. estimates (depending on a calculation technique), they spend about USD 10-25 billion a year on military space projects $^{9}$. As we can see, the U.S. space

\footnotetext{
${ }^{8}$ Dzonzi T., Prinsloo L. Facebook is Launching Rural Internet Access via Satellite for Africa.

URL: http://www.bloomberg.com/news/articles/2016-08-

31/facebook-to-start-africa-satellite-this-week-to-find-rural-users

${ }^{9}$ U.S. Defense Space-Based and-Related Systems: Fiscal Year 2015 Budget Comparison. URL: http://picxxx.info/pml.php? action $=$ GETCONTENT \&md5 $=897842 \mathrm{e} 89 \mathrm{~b} 380589 \mathrm{~b} 9132254 \mathrm{e} 223$ $5 \mathrm{c} 0 \mathrm{a}$
} 
strategy implies that the higher reliability of the commercial space market paves the way to better national security. Sustainable security depends on the reliability of the underlying system organizationally and technologically. Smooth and reliable operation of the entire space system is one of the most important tasks. Redundancy can be a solution. If a satellite is damaged or can perform some functions only, the system will basically remain in operation. If redundancy were an exclusive initiative of the government, this might result in financial and operational difficulties, since the strategy is very costly. Involvement of private companies may reduce costs and add reliability to the initiative, especially if we talk about different commercial satellites, which may serve for similar purposes. Currently, in the USA, private companies provide 80 percent of military telecommunications ${ }^{10}$. In the USA, the private providers also render launching services and bring satellites to the orbit, such as United Launch Alliance (ULA) ${ }^{11}$ and Space Exploration Technologies (SpaceX) $)^{12}$. Other private companies, such as Orbital ATK ${ }^{13}$ and Blue Origin ${ }^{14}$, may also join the above group of launching service providers.

\section{National Programs}

Advanced economies commercialize space activities through national and international programs.

European Union. Conglomerates of projects, called, for example, Europe 4.0., show how some fundamental issues might be solved. The United National Economic Commission for Europe describes systemic and structural rearrangements with the space industry

\footnotetext{
${ }^{10}$ Why the Military Needs Commercial Satellite Technology. URL: http://www.defenseone.com/technology/2013/09/whymilitary-needs-commercial-satellite-technology/70836/

${ }^{11}$ United Launch Alliance. URL: http://www.ulalaunch.com/

${ }^{12}$ Space Exploration Technologies.

URL: http://www.spacex.com/

${ }^{13}$ Orbital ATK. URL: https://www.orbitalatk.com/

${ }^{14}$ Blue Origin. URL: https://www.blueorigin.com/
}

becoming a cornerstone of this endeavor ${ }^{15}$. We refer to some statements of their program.

They call for ambitious projects for energy security, energy efficiency, environment, electricity market redesign and elimination of physical and administrative barriers impeding the free passage of power to Europe. Transport, logistics and space are declared as some of the cornerstones for common success in this transformation process. In this respect, Europe is an absolute leader in the global positioning system and builds Copernicus, one of the largest Earth observation data bases $^{16}$. This EU program is intended to develop the European information services through satellite-based observation of the Earth and in situ data. Copernicus obtains data from Sentinel satellites (20 satellites until 2030) and in situ systems, such as ground-based stations providing data from multiple Earth, marine and air sensors.

The value creation chain includes six dedicated segments of Copernicus services. These are observation data on the atmosphere, seas, oceans, land, climate, emergency situations, security.

Data from Copernicus can be utilized by ultimate users widely and differently, including urban district administration, sustainable development and environmental protection, regional and local planning, agriculture, forestry and fishery, healthcare, civil defense, infrastructure, transport, mobility, and tourism.

Based on Copernicus services and data, many value added services can accommodate for specific social or business needs, thus opening up new business opportunities.

Copernicus is coordinated and managed by the European Commission. Observation infrastructure is developed under the auspices

\footnotetext{
${ }^{15}$ Will Europe Lead the Fourth Industrial Revolution? URL: https://www.weforum.org/agenda/2016/01/will-europe-leadthe-fourth-industrial-revolution/

${ }^{16}$ Copernicus. URL: http://www.copernicus.eu/
} 
of the European Space Agency, European Environment Agency and member States in situ.

Europe may hugely benefit from reducing traffic congestion, improving the air quality and viability of cities and decreasing the greenhouse effect. Consequently, there should be enhanced and integrated infrastructure, broad electrification and use of alternative fuel for cars, upgraded logistics with relevant equipment and more precise navigation. However, the aspects should be on the agenda of the legislature. In December 2015, Russia produced to the EU its aviation strategy, focusing on car transport, space and infrastructure in 2016-2017.

This process should be concurrent with the digital development of Europe. As for digital power services, Russia should be certain that consumers will be able to control and use their consumption data as effectively as possible, while the intellectual stewardship of the network is expanding.

Data are often called crude oil of the digital revolution. Innovative companies will have knowledge of their valuable use and huge benefits that consumers and society may have. Therefore, digital infrastructure, intellectual data analysis, Open Source approach and respect to data confidentiality, as the last but not least condition, will be key aspects linking power engineering, transport and the Internet along the same information superhighway, which will lay the basis for the future industrial platform.

Russia finds itself within the new economic paradigm of Europe 4.0. Europe intends to create the pure digital economy based on sustainability and high profitability in pursuit of social interests. Transformational breakthrough and advancement business models should spur economic and sustainable growth, concurrently improving the wellbeing of various social strata, including the most vulnerable ones. Europe 4.0 is about smart and fair Europe ${ }^{17}$.

United States of America. As the market of space services grew, new regulatory efforts were taken. Considering intentions of private companies to launch thousands of new satellites, there should be new and updated rules governing spaceflights. New would-be industries of space economy, such as asteroid mining, should be subject to relevant regulations and acts of international laws. For example, Moon Express ${ }^{18}$ undertaking lunar exploration missions made everyone question which governmental institution or agency, if any, should regulate such missions and what are their responsibilities. Private companies are also uncertain about some possible missions and permissions they may count on. Some of the above problems are virtually technicalities, but others concern ecology. Many of the problems are raised in accordance with the effective regulatory approaches, while some of them can be governed by new rules. Commercial space makes consider national security and international relations in broader sense. Any strategy that have some connection with space should necessarily account for such variables.

Frequency of collisions, troubles and space catastrophes proves that regulatory mechanisms should be thoroughly elaborated. The issues can be segmented as follows: technological complexity of space activity, regulatory imperfections, national security implications, international disputes.

Space voyages are technically complex and dangerous. Space Shuttle program for recurring spaceflights lost two shuttles out of five $^{19}$. Accidents happened throughout the entire 30-year period of the program.

\footnotetext{
${ }^{7}$ The end of statements of the EU program.

${ }^{18}$ Moon Express. URL: http://www.moonexpress.com/

${ }^{19}$ Shuttle Fleet Left Mark in Space, Hearts.

URL: https://www.nasa.gov/mission_pages/shuttle/flyout/shuttlea chievements.html
} 
However, the loss of fourteen people on board of the shuttles still exceeds total losses recorded in other space launch systems ${ }^{20}$.

Commercial launch programs take their accident toll too. In 2014, the accident of SpaceShipTwo owned by Virgin Galactic killed the co-pilot and injured the pilot heavily ${ }^{21}$.

In June 2015, SpaceX Falcon exploded just after a launch, destroying the payload designated for ISS ${ }^{22}$. On September 1, 2016, the disintegration of $\mathrm{SpaceX}^{23}$, which took place during the on-land testings, destroyed the satellite equipment owned by Facebook and intended to ensure access to the Internet in some parts of Africa.

Reusable launch boosters pose another technological challenge. Both Blue Origin $^{24}$ and SpaceX ${ }^{25}$ demonstrated the reusable launch technology and intended to use the same launchers in order to cut total launching costs. Neither company reached the phase of carrying governmental or commercial payload, but they are nearing this moment. Blue Origin has used its rocket for various tests, while SpaceX signed a contract for launching a commercial satellite based on a reusable booster ${ }^{26}$.

\footnotetext{
${ }^{20}$ Three accidents in the U.S., four ones of Russia. The number of deadly accidents does not correspond with the number of missions. Data on other countries were not found.

${ }^{21}$ Commercial Space Launch Accident - SpaceShipTwo. URL: http://www.ntsb.gov/news/events/Pages/2015_spaceship2 BMG.aspx

${ }^{22}$ Wall M. SpaceX Rocket Explosion Likely Caused by Faulty Strut, Elon Musk Says. URL: http://www.space.com/29994spacex-rocket-explosion-cause-faulty-strut.html

${ }^{23}$ Calandrelli E. Here's What We Know about the SpaceX Explosion. URL: https://techcrunch.com/2016/09/01/here-whatwe-know-about-the-spacex-explosion/

${ }^{24}$ Malik T. Blue Origin Aces 4th Reusable Rocket Launch (and Landing) in Live Webcast. URL: http://www.space.com/33214blue-origin-lands-reusable-rocket-4th-time-webcast.html

${ }^{25}$ Wall M. SpaceX Lands Another Rocket During Space Station Cargo Launch. URL: http://www.space.com/33443-spacexdragon-launch-rocket-landing.html

${ }^{26}$ De Selding P. SpaceX to launch SES-10 on previously flown Falcon 9 this year. URL: http://spacenews.com/spacex-to-launchses-10-satellite-on-reused-falcon-9-by-years-end/
}

The space industry is growing intensely, dealing with a myriad of possible challenges - from dust to radiation. Companies planning to operate in the outer space, i.e. from asteroid mining to exploration missions, need to tackle a wider and unpredictable spectrum of challenges. After they solve expectable matters, such as radiation shielding or effective fuel production, they should be prepared for new ones that they might not event predict. Contemporary knowledge and scientific achievements make this obvious. However, space debris technically puzzles companies targeting at orbital projects, with all possible issues being studied and classified.

With the number of governmental and private satellites increasing, space debris (idle satellites, parts of boosters, metal, etc.) follow the same trend. In 2013, NASA reported on over 500,000 pieces of space debris orbiting around Earth ${ }^{27}$.

The issue has aggravated, remaining a genuine threat to spacecraft. For instance, the international space stations had to change its orbit in order to avoid a possible clash. In 2014, satellites had to make more than 120 maneuvers to mitigate the risk of clashing with space debris ${ }^{28}$. In 2009, two operational satellites collided for the first time $^{29}$. Experience shows that space debris can be generated very rapidly. Just two instances the collision of satellites in 2009 and deliberate destruction of a satellite by China in 2007 - were estimated to generate one third of the observable orbital debris.

\footnotetext{
${ }^{27}$ Garcia M. Space Debris and Human Spacecraft. URL: http://www.nasa.gov/mission_pages/station/news/orbital_de bris.html

${ }^{28}$ Weedon B. Why Outer Space Matters: Brian Weedon on Natural and Human-Generated Threats on Satellites. URL: http://intercrossblog.icrc.org/blog/why-outer-space-mattersbrian-weeden-on-natural-and-human-generated-threats-onsatellites

${ }^{29}$ David L. Effects of Worst Satellite Breakups in History Still Felt Today. URL: http://www.space.com/19450-space-junk-worstevents-anniversaries.html
} 
Two solutions are usually considered.

1. Special-purpose missions should be sent to destroy some of the largest parts of space junk.

2. Future missions should have technology on-board to remove themselves.

RemoveDebris ${ }^{30}$, a pioneering mission and financed by the European Union, will be the first to test the space junk capturing concept of a net and harpoons in orbit. The mission to be launched at the end of 2018 will carry two artificial parts of space junk (two small CubeSat) and use them to test new technology. e.Deorbit, a planned debris removal mission of the European Space Agency (ESA), which is to be launched in 2024. The Japan Aerospace Exploration Agency (JAXA) has conducted its own experiment - KITE - to deploy a 700-meter tether to pull a satellite closer to Earth and accelerate its breakup. Unfortunately, this attempt ended in failure ${ }^{31}$.

Space rubbish may grow into even a more menacing issue in the future. Companies, such as OneWeb or SpaceX, suggested launching huge fleets (constellations) of satellites into space, carrying from several hundreds to several thousands of satellites. It is not difficult ti imagine that the risk of collision increases dramatically after this is done. The companies and their respective agencies will have to prove that they have solutions in place to deal with the space junk issue. They are expected to produce convincing evidence that their satellites have self-removal technology, and they know how to remove broken-down satellites out of space.

\footnotetext{
${ }^{30}$ Forshaw J. How Can We Fix the Space Junk Problem? A Net and a Harpoon, Say Aerospace Engineers.

URL: https://www.ge.com/reports/can-fix-space-junk-problemnet-harpoon-say-aerospace-engineers/

${ }^{31}$ Clark S. Japanese Cargo Ship Ends Mission after Space Debris Experiment Flounders.

URL: https://spaceflightnow.com/2017/02/06/japanese-cargo-shipends-mission-after-space-debris-experiment-flounders/
}

\section{International Relations}

International relations in space permeate various aspects, with the security not being their only pursuit. There should be notes legal and economic challenges arising from the commercialization of space. During the Cold War, the United States and Soviet Union did come to an agreement and signed the Treaty on Principles Governing the Activities of States in the Exploration of States in the Exploration and Use of Outer Space, including the Moon and Other Celestial Bodies (The Outer Space Treaty) ${ }^{32}$. The Outer Space Treaty ruled out the situation when any Superpower appropriates part of the Moon or other planets. However, as of the Outer Space Treaty date, military expansion and ground consequences were still possible. However, the States reached an accord. Private companies are granted access to space, but the liability is assigned to their respective countries of origin $^{33}$. Furthermore, the countries will be responsible for private entities in space, but space activities of nongovernmental organizations (NGOs) should be authorized and continuously supervised by respective bodies in the NGO's country of origin.

The Outer Space Treaty is virtually an ideological compromise between the Superpowers. Many years have passed and the space market saw new ambitious actors appear, to say nothing about new challenges awaiting decent solutions ${ }^{34}$. The Treaty seems meaningful and sensible if national governments of the contracting States assume responsibility for any space activities they carry out. However, the connection of public authorities, public organizations and business

\footnotetext{
${ }^{32}$ The Treaty was ratified with the UN General Assembly Resolution of December 19, 1966.

URL: http://www.un.org/ru/documents/ decl_conv/conventions/outer_space_governing.shtml

${ }^{33}$ United Nations Treaties and Principles on Outer Space. URL: http://www.unoosa.org/pdf/publications/STSPACE11E.pdf

${ }^{34}$ Koerth-Baker M. Who Makes the Rules for Outer Space? URL: http://www.pbs.org/wgbh/nova/next/space/space-law/
} 
may perish since private entities implement their space missions which do not have direct relation to social life.

Technicalities of the Treaty pose another problematic question. While the Treaty prohibits to claim sovereignty over parts of the Moon and other celestial bodies, it also forbids any interventions into space equipment of other countries. The pact may allow companies or even countries claim the ownership of some part of the Moon, other celestial bodies ${ }^{35}$. There is no satisfactory decision so far on the basis of the existing regulations, which would settle the undesirable situation when companies would share parts of the Moon occupied with their equipment.

We may refer to American regulatory practices in space and evaluate how the international relations influence the general position the U.S. government takes and specific actions it undertakes.

Whereas the USA and other countries take ultimate international responsibility, notwithstanding whether such activities are carried out by governmental institutions or non-governmental organizations, authorities have nothing to do but control the uncertainty through regulations. The U.S. government is the head of the U.S. space industry. Thus the more the latter evolves, the higher the pressure on the first. This probability rises because the emergence of new space activities reveal some regulatory gaps, with national security tensions in space escalating as new countries embark on space exploration.

Technological Advancement. Many longstanding ideas for space operations have proved to be feasible just recently. It is obvious that non-viable activities shall not be regulated if its social benefits are unclear. Asteroid mining or commercial lunar mission

\footnotetext{
${ }^{35}$ Powell A. Eternal Light, Up for Grabs.

URL: http://news.harvard.edu/gazette/story/2016/07/eternal-lightup-for-grabs/
}

were considered fantastic ventures for a long time. However, once Moon Express ${ }^{36}$ was permitted to send a mission to the Moon, and new risky propositions ${ }^{37}$ for asteroid mining were expressed $^{38}$, new space and commercial ventures no longer seem so fantastic and unreal.

Predominance of State. The U.S. government is the only customer which dominates the entire space industry of the USA since its inception. Nowadays SpaceX performs major governmental orders ${ }^{39}$ and cooperates with NASA $^{40}$. However, future developments are yet to come.

Colonizing Mars is a strategic goal of SpaceX ${ }^{41}$. We should mention another project for asteroid mining unfolding ${ }^{42}$ and pursuing its own interests. Moon Express treats the Moon as a destination for commercial reconnaissance and research.

As we can see today, the U.S. government has created a relatively permissive regulatory framework. This conclusion is based on the analysis of the U.S. Commercial Space Launch Competitiveness $\mathrm{Act}^{43}$, which was obviously adopted to prompt American companies to quicken and intensify space

\footnotetext{
${ }^{36}$ Moon Express. URL: http://www.moonexpress.com/

${ }^{37}$ Space: A Sudden Light. URL: http://www.economist.com/ technology-quarterly/2016-25-08/space-2016

${ }^{38}$ Bonin G., Foulds C., Armitage S., Faber D. Prospector-1: The First Commercial Small Spacecraft Mission to an Asteroid. URL: http://deepspaceindustries.com/wpcontent/uploads/2016/08/Prospector-1-SmallSat-2016-v01.0.pdf

${ }^{39}$ Gruss M. SpaceX wins $\$ 82$ million contract for 2018 Falcon 9 launch of GPS 3 satellite. URL: http://spacenews.com/spacexwins-82-million-contract-for-2018-falcon-9-launch-of-gps-3satellite/

${ }^{40}$ De Selding P. SpaceX wins 5 new space station cargo missions in NASA contract estimated at $\$ 700$ million. URL: http://spacenews.com/spacex-wins-5-new-space-stationcargo-missions-in-nasa-contract-estimated-at-700-million/

${ }^{41}$ Wall M. Now Is the Time to Colonize Mars, Elon Musk Says. URL: http://www.space.com/31388-elon-musk-colonize-marsnow.html

${ }^{42}$ Planetary Resources.

URL: http://www.planetaryresources.com/

${ }^{43}$ U.S. Commercial Space Launch Competitiveness Act. URL: https://www.congress.gov/114/plaws/publ90/PLAW114publ90.pdf
} 
exploration missions. As emerging companies change their pace of their spaceflights, the commercial use of space gets into balance. Enjoying the relative freedom of actions, companies are set to satisfy their interests and get use of regulatory loopholes. The United States of America may quickly leave this favorable environment. International tensions may urge the government to consider whether benefits of space activities are worth those troubles arising on the ground.

International discords in space can cause additional restrictions of space operations. Passing the law on space-based resources and their exploitation ${ }^{44}$, the USA did not stipulate rules for licensing space mining operations. As experience shows, the regulatory framework for commercial use of outer space will not laid down until the first cases take place. Right at the point, various international and domestic circumstances will reveal their impact on the way regulatory bodies will treat space trade and profit-making activities there. Although there are not recurring instances and practices, it is necessary to think about the future and envisage possible challenges regulatory bodies may face as outer space will be further explored.

\section{Governmental Involvement}

Private businesses tend to engage in space activities in the bottom-up fashion, if we look at the value creation chain. Observing the tendency, we make a preliminary conclusion about the importance of the government intervention, considering that the State has had monopolistic authorities just recently in the sphere. It would be basically premature to say that the State is no longer a monopolist, considering the case of Roscosmos State Corporation. However, with all the latest international trends and international private projects in $\operatorname{mind}^{45}$, the outlook of the

\footnotetext{
${ }^{44}$ Koerth-Baker M. Who Makes the Rules for Outer Space? URL: http://www.pbs.org/wgbh/nova/next/space/space-law/

${ }^{45}$ International Forum of Commercial Space Industry and UAVS - INSPACE FORUM 2018. Moscow, 2017.
}

diversified space industry ceases to seem so unrealistic. Certainly, it is important to monitor that aerospace enterprises continue their sustainable development [8, 9] and integration [10]. It is also vital to ensure the economic security of science-intensive and high-tech production [11], have knowledge to evaluate the feasibility of innovative space projects [12]. Some organizational rearrangements may help the government take more beneficial positions and subsequently better perform its regulatory functions. Governmental reforms of business may ensure that market take a correct and positive development trajectory, having appropriate structure and growth rates.

It is beneficial for the government to encourage and stimulate the space economy since it will spur innovation and contribute to social advancement. Free competition in the space economy will reduce governmental spending on launches and satellite management. What measures may the government undertake in the space industry? The Russian commercial space market is yet very fragile, being in its infancy. While the U.S. space market is rather mature to put pressure on the U.S. government, the Russian private initiatives are feasible only if they are implemented in the favorable political environment. In some circumstances, communication, transparent and clear decision-making may have a very positive impact.

Seeing the commercial environment, i.e. global environment, governmental regulators should support private initiatives as much as possible. Missions should get necessary permissions, with governmental bodies sorting out whether some mission will be hazardous for the society or national security. If the government fails to motivate a refusal within a defined period of time, the mission should be approved. The mission application

URL: https://inspaceforum.ru/ru/results-2017 (In Russ.) 
process should be clearly stipulated. Decisions should account for propositions of various organizations or enterprises. Decisions taken for purposes of national security should be traceable, understandable and, if needed, subject to further examination and scrutiny. Considering all processes of the space industry, the space market actors should pursue the self-sufficiency, rather that simply privatize governmental functions.

Transfer of ground legal practices may also turn into a fruitful process. The government may rely on the effective laws in coordinating some issues, rather than formulating a new special legal framework. For example, the law on offenses can serve for sorting out some possible issues of space activities, at least in cases involving two Russian companies. Discrepancies of the international and national laws are another point to consider. There will be a set of possible solutions that will work for specific cases. Asteroid mining can be likened with deep water exploration, and removal of orbital debris will require an international agreement, international coordination and, perhaps, cooperation.

If rules are needed, they should be coherent, unambiguous and concrete. Decision-making should be transparent and consistent. The government should not set up special rules for some types of space activities if it can borrow identical practices from other industries. It should clearly define which processes and products should be authorized on the governmental level and to what extent they should be monitored.

Definitely, it shall be the government to forecast the development of the space industry and govern this activity strategically. However, the government should refrain from the micromanagement approach to the commercial use of outer space. Avoidance of burdensome regulation and governance is the most complicated task. Nevertheless, merely facing some challenges, the government should not make its policy too restrictive and stringent, especially when the liberalization strategy clearly and obviously generates a more positive effect.

\section{Conclusion}

Currently, the global competition in the aerospace industry demonstrates two key tendencies, i.e. a growth in the private sector and emergence of new business models, and intensifying internationalization of value creation chains for space products. Relying on the dialectical analysis, synthesis, statistical observations, comparison, induction, deduction, historical and logic methods and data of reports prepared by governmental institutions and renowned research organizations for the space industry, scientific publications of the Russian and foreign experts, we found out that the current development trends of the aerospace industry gradually shape its operational structure similar to the network economic model. Various actors of space activities were found to have considerable opportunities and risks at the same time in the dynamic organizational environment. Reviewing the role of the government, we account for new tendencies and note that it should hold necessary levers to keep control over processes in the aerospace industry.

What seems important and vital is to undertake private business support measures in the aerospace industry of Russia. Considering the organizational structure of the Russian aerospace industry, we suggest taking efforts below in order to stimulate innovation and commercial focus of space activities.

Tackling the inaccessibility of foreign innovation and trying to stream them into Roscosmos Corporation, a vertically structured organization owned by the State (i.e. consequently being isolated), Russia 
should establish strategic alliances with competent foreign partners to implement joint science-intensive ventures in outer space. Drawing upon joint research and pursuing technological advancement, rather than merely trade contracts, such unions will contribute to export opportunities of the aerospace industry and maintain its competitiveness.

To successfully sell applied space services based on governmental space vehicles domestically and abroad, the space market actors should carry out market research into various segments and strive to subsequently commercialize the project from the very beginning. In the Russian aerospace industry, academia and enterprises have rather good cooperation ties. The problem is that the system lacks the consumer-oriented focus since the Russian space activities were conceived without market projections. The solvable clientele is needed since it will ensure the feedback from consumers and motivate for further tactical and technological improvements of space vehicles. For example, it is worth considering an obligation to pay for applied space services even on the part of the government.

$R \& D$ for dual purpose space systems should be priority investment for the government to save budgetary funds. Dual purpose space systems will close the gap between global leaders and Russia in terms of communications, broadcasting, Earth remote sensing.
Space-faring nations continuously tend to cut their spending on civil programs. However, total funds increase as they lure private investors into space activities. Private investment is used in defense programs, with the military sector purchasing relevant information from private companies operating Earth remote sensing satellites and delivering communication services, thus supporting private initiatives, on the one hand, and save budgetary funds earmarked for $R \& D$, production and launch of special-purpose military spacecrafts, on the other hand.

More active involvement of private business makes space projects more cost effective, serves as an innovation pipeline in management and commercialization, though requiring considerable financial injections from the State and transports assets and technologies to other companies. The government preserves the critical role in ensuring the competitiveness of the national aerospace industry. It should have refined mechanisms in place to keep control and influence the market as competition changes. When making strategic decision, it should consider the specifics of the organizational and structural design of the aerospace industry.

To make the Russian aerospace industry competitive in the long run, with its manufacturing segment being wholly Stateowned, the government should take efforts to improve the commercialization of the Russian space products and develop the marketing practice, secure beneficial scientific alliances with reliable foreign partners.

\section{Acknowledgments}

The article was supported by the Russian Foundation for Basic Research (RFBR), grant № 16-06-00018, Mathematical and Logical-Linguistic Modeling of Organizational and Economic Mechanisms to Mitigate and Compensate Risks of Innovative Projects for Creating High-Tech Products with Long Life Cycle (the Rocket and Space Technology Case). 


\section{References}

1. Mekaeva E.M. [Commercialization of space]. Aktual'nye problemy aviatsii $i$ kosmonavtiki = Topical Issues of Aviation and Cosmonautics, 2016, vol. 2, no. 12, pp. 618-620. (In Russ.)

2. Firulev O.V., Erygin Yu.V. [Commercialization of the innovation potential of integrated corporate structure in the rocket and space industry]. Upravlenie ekonomicheskimi sistemami, 2017, no. 9, pp. 24-33. (In Russ.) URL: http://uecs.ru/index.php? option $=$ com_flexicontent $\&$ view $=$ items $\& i d=4543$

3. Polukhin I.V. [Commercialization of innovations of the enterprises in the rocket-space industry]. Reshetnevskie chteniya $=$ Reshetnev Readings, 2016, vol. 2, no. 20, pp. 388-391. (In Russ.)

4. Krikalev S.K., Saprykin O.A. [Manned lunar infrastructure and commercialization of flights to the Moon]. Pilotiruemye polety v kosmos, 2016, no. 1, pp. 47-62. (In Russ.)

5. Ivanitskaya V.V., Korepanova E.G. [Private space organizations and commercialization of space projects]. Aktual'nye problemy aviatsii $i$ kosmonavtiki $=$ Topical Issues of Aviation and Cosmonautics, 2015, vol. 2, no. 11, pp. 300-302. (In Russ.)

6. Makarov Yu.N., Khrustalev E.Yu. [Bidding mechanism of contracting for the most advanced high technology product development (the rocket and space technology case)]. Finansovaya analitika: problemy i resheniya = Financial Analytics: Science and Experience, 2012, no. 21, pp. 2-10. URL: https://cyberleninka.ru/article/v/konkursnyymehanizm-zaklyucheniya-kontraktov-na-razrabotku-naukoemkoy-ivysokotehnologichnoy-produktsii-na-primere-raketno (In Russ.)

7. Makarov Yu.N., Khrustalev E.Yu. [Financial and economic analysis of rocket and space industry of Russia]. Audit i finansovyi analiz = Audit and Financial Analysis, 2010, no. 2, pp. 145-155. (In Russ.)

8. Endovitskii D.A., Lyubushin N.P., Babicheva N.E., Kupryushina O.M. [From the assessment of organization's financial standing to the integrated methodology for analysis of sustainable development]. Ekonomicheskii analiz: teoriya i praktika $=$ Economic Analysis: Theory and Practice, 2016, no. 12, pp. 42-65.

URL: https://cyberleninka.ru/article/v/ot-otsenki-finansovogo-sostoyaniya-organizatsii-kintegrirovannoy-metodike-analiza-ustoychivogo-razvitiya (In Russ.)

9. Lyubushin N.P., Babicheva N.E., Konyshkov A.S. [Sustainable development: Evaluation, analysis, forecasting]. Ekonomicheskii analiz: teoriya i praktika = Economic Analysis:

Theory and Practice, 2017, vol. 16, iss. 12, pp. 2392-2406. (In Russ.)

URL: https://doi.org/10.24891/ea.16.12.2392

10. Khrustalev O.E. [Mechanisms and methods for high-tech enterprise integration]. Finansovaya analitika: problemy i resheniya $=$ Financial Analytics: Science and Experience, 2012, no. 25, pp. 24-30. URL: https://cyberleninka.ru/article/v/mehanizmy-imetody-integratsii-naukoyomkih-proizvodstv (In Russ.) 
11. Bendikov M.A., Khrustalev E.Yu. [Economic security of science-intensive production]. Voprosy Ekonomiki, 1999, no. 9, pp. 119-125. (In Russ.)

12.Khrustalev O.E., Khrustalev Yu.E. [Instrumental methods of assessing the feasibility of a knowledge-based investment project]. Ekonomicheskii analiz: teoriya i praktika = Economic Analysis: Theory and Practice, 2011, no. 27, pp. 8-18.

URL: https:/cyberleninka.ru/article/v/instrumentalnye-metody-otsenki-realizuemostinaukoemkogo-investitsionnogo-proekta (In Russ.)

\section{Conflict-of-interest notification}

We, the authors of this article, bindingly and explicitly declare of the partial and total lack of actual or potential conflict of interest with any other third party whatsoever, which may arise as a result of the publication of this article. This statement relates to the study, data collection and interpretation, writing and preparation of the article, and the decision to submit the manuscript for publication. 